\title{
Screening of Antibacterial Metabolites from Marine Soil, Kodiyampaiayam, Tamilnadu
}

\author{
S Satheesh Kumar, Uma C, MuthulakshmiK, SivagurunathanP *
}

\begin{abstract}
The marine environment is a rich resource for isolating exploited microorganisms. In recent years, antibiotics have become important in this study of new antibiotics that show antiviral, anticoagulant and cardiac properties. Soil samples were collected from different area and isolated the bacterial colonies were separately streaking in agar plates (KP1, KP3, KP6, KP7 and KP9). The bacteria were done by morphology characteristic after that bacterial crude extract was taken separately. The crude extract was used in antibacterial activity against human pathogenic bacteria. There KP 7 and KP 9 havethe highest activity in B. subtilis and S. pyogenes rest of the samples also had activity comparing to these samples (KP 7 and $K P$ 9) is highest zone inhibition developing. The marine sediment having so many microbes and secondary metabolites, therefore,the most useful drug development..
\end{abstract}

Keywords : Antibacterial activity, Marine, crude extract, Soil sample, Bacteria.

\section{INTRODUCTION}

The sea contains $70 \%$ earth and $80 \%$ plant and animal tissues. There are many structurally unique metabolites in the oceans, other resources in life and dead forms. About 10,000 metabolites were isolated from various marine organisms. Of these, $37 \%$ were isolated from sponges, $21 \%$ were co-accelerated, $18 \%$ were from microorganisms, $9 \%$ from algae, $6 \%$ from croutons, 5\% from mollusks, $2 \%$ from mollusks and $1 \%$ from bryozoans [17].

The marine environment is a rich resource for isolating exploited microorganisms. In recent years, antibiotics have become important in the study of new antibiotics that show antiviral, anticoagulant and cardiac properties. These active compounds can act as typical systems for the discovery of new drugs. Many organisms have developed complex mechanisms of adaptation and self-protection for survival, often associated with the production of structurally bioactive compounds that are structurally distinct. Marine bacteria produce broad-spectrum antibiotics and a variety of toxins such as tetrodotoxin, Cytoxan toxins, iguanian toxins and brevotoxin, which are useful in neurophysiological and neuropsychological studies. The production of antimicrobial

Revised Manuscript Received on November 05, 2019.

Dr. SivagurunathanP*, Department of Microbiology, Annamalai University, Annamalainagar-608002,

Corresponding Email: sivaguru1981@gmail.com.

S Satheesh Kumar, Department of Microbiology, Annamalai University, Annamalainagar-608002. Annamalainagar-608002,

MuthulakshmiK, Department of Microbiology, Annamalai University, Annamalainagar-608002.
Uma C, Department of Microbiology, Annamalai University,

compounds appear to be common in most bacteria. Antimicrobials are substances that kill or inhibit the growth of microorganisms such as bacteria, fungi or viruses. The discovery of antibiotics revolutionized the world of medicine. The low detection rate of new drugs from fixed land-based sources encouraged the evaluation of new sources of chemically different target compounds [19].

The discovery of antibiotics over 8 decades in the past revolutionized the treatment of infections, once turning lethal diseases into workable fitness issues [4]. The availability of effective antibiotics has revolutionized public health and is accountable for allowing endless advances in medical care; This has been better by powerful antibiotic healing procedures, which have created a crisis in which many antibiotics are not powerful in opposition to minor infections. These infections often lead to an boom in the wide variety of hospitalizations, more remedy failures and persevered resistance to pathogens [24]. From the Eighties to the early 2000 s, there has been a ninety\% lower in the approval of recent antibiotics. Due to scientific, regulatory and financial constraints, many organizations have shied far from drug development, showing that antibiotic development is much less appealing than fantastically value-effective healing regions [16]. Microbes preserve to withstand; the antibiotic tax maintains to say no and most of the people of the general public remains blind to this critical situation. This has caused the cutting-edge situation in which infectious illnesses kill almost 13 million human beings worldwide, yearly, which continues to increase and make a contribution to resistance genes.

Nature has been a supply of scientific elements for heaps of years. An astonishing quantity of cutting-edge medicine has been remoted from microorganisms, primarily based on their use in conventional medication. In the final century, microorganisms have played an more and more critical position inside the manufacturing of antibiotics and different drugs [11]. The significance of bacterial and terrestrial fungi as sources of incredible biologically energetic metabolites has been round for over half a century. As a end result, the most important a hundred and twenty drugs (penicillin, cyclosporine A, adriamycin, and so on.) are derived from terrestrial microorganisms today [1].

A new study focuses on marine microorganisms with great interest [10]. At first glance, the expected enormous biodiversity of marine microbes may be of interest to the study [18]. Although marine microorganisms are not well defined in terms of classification, global studies indicate that the richness of microbial diversity in global oceans is a promising limit to the discovery of new drugs [2].

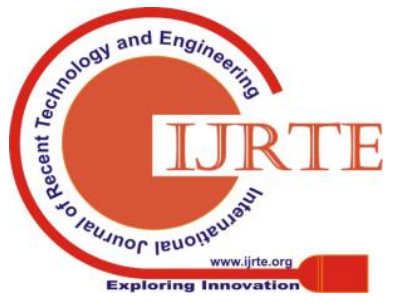


The marine bacterial metabolites has having antibacterial resistant against human pathogen bacteria.

\section{MATERIALS AND METHODS}

\section{A. Study area and Soil collection}

The samples had been accrued from Cuddalore District, Tamil Nadu. In this location, the soil consists of sediments together with alluvium, laterites, brown sands, and so forth. Hydromorphic saline soils arealso observed within the regions and predominantly, gentle varieties of soil.

The soil samples were collected from 6 different locations (Kodiyampalayam, Puthukuppam, MGR thittu, Parangipettai,Puthupettai, and Velingarayanpettai) in differ field at Cuddalore District, Tamil Nadu, India.The samples had been interior deep 5-15 cm and approximately 10 to $30 \mathrm{~g}$ of the soil changed into amassed in a sterile tube and transported into a laboratory and stored at 4 oC.

\section{B. Isolation of soil bacteria}

Soil micro organism have isolated by means of the usual serial dilution plate method. At $1 \mathrm{~g}$ of every soil pattern became weighed and soaked in $10 \mathrm{ml}$ of sterile physiological saline. The samples had been then serially diluted. Out of the 4 dilutions, $0.1 \mathrm{ml}$ from each dilution (one zero one,102, 103 and 104) of every sample were used to prepare nutrient agar unfold plates. The plates were incubated temperature at $37 \mathrm{oC}$ for twenty-four to 48hours to find out a bacterial colony. The colonies which showed special morphology have been picked up and streaked on nutrient agar plates in part so that you can obtain pure isolated colonies. The pure subculture was saved at four ${ }^{\circ} \mathrm{C}$ for subsequent studies.

\section{Identification of isolated bacteria}

Morphological characterizations of the remoted micro organism have been performed using Gram's Staining technique and Biochemical exams. 24 hours of old nutrient broth cultures of every isolate..

\section{Antibacterial Activity}

The micro organism which showed high-quality effects in number one screening, decided on for secondary screening by way of the disc diffusion technique. In this approach, to start with, all the 6 check pathogens had been swabbed separately on to 6 exceptional Muller Hinton Agar plates the usage of a sterile cotton swab. Immediately after swabbing, the disc became assembled for plates the disc changed into loaded with $20 \mu \mathrm{l}$ metabolite of the bacterium. The antibiotic disc Erythromycin $20 \mu \mathrm{l}$ turned into used as a positive control. After $24 \mathrm{~h}$ of incubation, the plates had been checked for the presence of the region of inhibition. The duration of zones produced via both the micro organism and the antibiotic disc have been measured as it should be the usage of antimicrobial interest measuring scale.

\section{E. Determination of Minimum Inhibitory Concentration (MIC)}

MIC became determined in bacterial metabolites showing antimicrobial activity with the aid of with minor adjustments. Briefly, a hundred $\mu \mathrm{l}$ Muller-Hinton broth (Hi media) and numerous focused bacterial metabolites have been organized and transferred to 90 well plate to obtain dilutions of the active extract from 1.0 to one hundred twenty $\mathrm{mg} / \mathrm{ml}$. Then,
$10 \mu \mathrm{l}$ of the take a look at organisms had been introduced to the new tradition (final concentration of 1 x $106 \mathrm{CFU} / \mathrm{ml}$ ). The plates have been incubated for $24 \mathrm{~h}$ at $37^{\circ} \mathrm{C}$. The microbeswas described as the bottom attention of the extract to manipulate the visible growth of the tested organisms..

\section{F. Determination of Minimum Bactericidal Concentration (MBC)}

To determine the MBC, Muller Hinton agar plates in 90 properly confirmed no sizable boom; The plates were incubated for $24 \mathrm{~h}$ at $37^{\circ} \mathrm{C}$. MBC become defined as the lowest extraction awareness that did no longer show bacterial increase. White methanol and tetracycline (Hi media) have been used as a fine manipulate. Once MBC turned into, subtype activity in bacterial boom changed into decided. For this motive, the concentrations of seventy five, 50 and $25 \%$ MBC in 96 nicely plates had been tested, and the number of microbial cells changed into carried out using the plate counting approach as described above.

\section{RESULTS}

\section{A. Collection of soil samples}

The soil samples were collected from the different area for Cuddalore District, Tamil Nadu. That area showed in (Table I).

Table-I: Isolation of Bacteria from a marine soil sample

\begin{tabular}{|l|l|l|l|}
\hline $\begin{array}{l}\text { S. } \\
\text { No }\end{array}$ & Places & $\begin{array}{l}\text { Number of } \\
\text { isolates } \\
\text { (CFU/g) }\end{array}$ & $\begin{array}{l}\text { Code for } \\
\text { different } \\
\text { isolates }\end{array}$ \\
\hline 1 & Kodiyampalayam & 5 & $\begin{array}{l}\text { KP, KP3, KP6, } \\
\text { KP7, KP9 }\end{array}$ \\
\hline 2 & Puthukuppam & 2 & PK1,PK7 \\
\hline 3 & MGR thittu & 3 & MT3,MT5,MT8 \\
\hline 4 & Parangipettai & 3 & PP1,PP2, PP3 \\
\hline 5 & Puthupettai & 4 & $\begin{array}{l}\text { PT1,PT2, PT6, } \\
\text { PT8 }\end{array}$ \\
\hline 6 & Velingarayanpettai & 2 & VP1,VP2 \\
\hline
\end{tabular}

The soil samples after collecting were used in the spread method and were done by Nutrient agar plates. After that sample was developed by the bacterial colony. The colony more than grow in (KP1, KP3, KP6, KP7 and KP9) samples compared to other samples. That samples have taken to further activity.

\section{B. Isolation and maintenance of microbial isolates}

The colony-forming devices (CFU) of each soil sample became numerous. The appropriate dilution became selected based totally on the plate having the countable variety of colonies. The maximum quantity of CFU became recorded in a soil pattern (Kodiyampalayam) and the minimal number of CFU was noticed in a soil sample (Puthukuppam\&Velingarayanpettai). Out of 6 soil samples screened five bacterial samples (KP1, KP3, KP6, KP7 and KP9) showed the antagonistic property at dilutions either104 or one zero five. KP7 possessed 3 colonies with hostile activity. Followed by using KP9, which had colonies. The rest of the 3 samples i.E. Pattern KP1, KP3 and KP6 had single colonies displaying antagonism (Table 2). 
Hence, these 5 (KP1, KP3, KP6, KP7 and KP9) adversarial bacteria have been decided on for similarly screening.

Table- II: Antagonistic activity of isolate bacterial samples

\begin{tabular}{|l|l|l|}
\hline No.sample & Code of bacteria & antagonistic activity \\
\hline 1 & KP 1 & + \\
\hline 2 & KP 3 & + \\
\hline 3 & KP 6 & + \\
\hline 4 & KP 7 & +++ \\
\hline 5 & KP 9 & ++ \\
\hline
\end{tabular}

(+) Minimum activity, (++) Mordent activity, (+++) Maximum activity

\section{Morphological characterization}

Morphological characterization of the microbial isolates wasdone by way of Grams staining which found out all of the 5 microbial isolateswere gram-fine. Among them, the unique gram-positive bacterialike Rod, long-chain Cocc and cocci have been discovered (Table III).

Table-III: Morphological characterization of isolate Bacteria

\begin{tabular}{|c|c|c|c|c|c|}
\hline $\begin{array}{l}\text { Biochemica } \\
\text { I test }\end{array}$ & KP-1 & KP-3 & KP-6 & KP-7 & KP-9 \\
\hline Indole & - & - & - & - & - \\
\hline Methyl Red & - & + & + & - & - \\
\hline VP & - & - & - & - & - \\
\hline Citrate & + & + & + & + & + \\
\hline $\begin{array}{l}\text { Triple Sugar } \\
\text { iron }\end{array}$ & $\begin{array}{l}\text { Alkalin } \\
\text { e bud } \\
\& \text { slant }\end{array}$ & $\begin{array}{l}\text { Acid } \\
\text { bud } \\
\text { Alkalin } \\
\text { e slant }\end{array}$ & $\begin{array}{l}\text { Acid } \\
\text { bud } \\
\text { \&slant }\end{array}$ & $\begin{array}{l}\text { Acid } \\
\text { bud } \\
\text { Alkalin } \\
\text { e slant }\end{array}$ & $\begin{array}{l}\text { Acid } \\
\text { bud } \\
\text { Alkalin } \\
\text { e slant }\end{array}$ \\
\hline Catalase & - & + & + & - & + \\
\hline Oxidase & + & + & + & - & + \\
\hline \multicolumn{6}{|c|}{ Morphological characteristics (Gram Staining) } \\
\hline $\begin{array}{l}\text { Colony } \\
\text { colour }\end{array}$ & $\begin{array}{l}\text { Pale } \\
\text { Yellow }\end{array}$ & White & White & White & Yellow \\
\hline $\begin{array}{l}\text { Cell } \\
\text { morphology }\end{array}$ & $\begin{array}{l}\text { Rod-sh } \\
\text { aped }\end{array}$ & $\begin{array}{l}\text { Cocci } \\
\text { shaped }\end{array}$ & $\begin{array}{l}\text { Rod-s } \\
\text { haped }\end{array}$ & $\begin{array}{l}\text { Rod-sh } \\
\text { aped }\end{array}$ & $\begin{array}{l}\text { Rod-sh } \\
\text { aped }\end{array}$ \\
\hline Forming & Chain & Cluster & Chain & Chain & Chain \\
\hline
\end{tabular}

\section{Antibacterial Activity}

The antibacterial interest utilized in remoted samples of unknown bacterial supernatant decided on by way of the maximum potential isolates KP 1,KP three,KP 6,KP 7 and $\mathrm{KP}$ 9 having full-size antibacterial hobby in opposition to 6 check human pathogens viz., 3 Gram-tremendous bacteria S. Aureus, B. Subtilis, S. Pyogenes and three Gram-terrible micro organism E. Coli, K. Pneumoniae, P. Aeruginosa. (Table four). Both the isolates showed positive consequences for B. Subtilis. And S. Aureus. The isolate KP 7 showed 17 $\mathrm{mm}$ and $\mathrm{KP}$ nine showed an $18 \mathrm{~mm}$ sector of inhibition respectively in opposition to B. Subtilis. The area of inhibition of antibiotic disc ER20 (Erythromycin) was27 mm towards B. Subtilis. Similarly,sixteen $\mathrm{mm}$ and $17 \mathrm{~mm}$ sector of inhibition was producedby isolate $\mathrm{KP} \quad 7 \quad \& \mathrm{KP} \quad 9$ respectively in opposition to $S$. Pyogenes. While the same old disc produced a quarter of inhibition was $25 \mathrm{~mm}$. During the screening in opposition to each the isolates KP 7 and KP 9reduced expanded zones of inhibition than the sector produced by means of popular disc Erythromycin. The region of inhibition produced by means of the isolate turned into greater towards B. Subtilis when as compared with S. Pyogenes. The antibacterial activity result was showed with the aid of Table 5. (fig 1)

Table-IV: Human pathogenic bacteria

\begin{tabular}{|l|l|l|}
\hline S.no & $\begin{array}{l}\text { Gram-positive } \\
\text { bacteria }\end{array}$ & $\begin{array}{l}\text { Gram-negative } \\
\text { bacteria }\end{array}$ \\
\hline 1 & $\begin{array}{l}\text { Staphylococcus } \\
\text { aureus }\end{array}$ & Escherichia coli \\
\hline 2 & $\begin{array}{l}\text { Streptococcus } \\
\text { pyogenes }\end{array}$ & $\begin{array}{l}\text { Klebsiella } \\
\text { pneumoniae }\end{array}$ \\
\hline 3 & Bacillus subtilis & $\begin{array}{l}\text { Pseudomonas } \\
\text { aeruginosa }\end{array}$ \\
\hline
\end{tabular}

Table-V: Antibacterial activity of the isolated bacterial crude extract

\begin{tabular}{|l|l|l|l|l|l|l|l|}
\hline \multicolumn{7}{|c|}{ Antibacterial activity of isolated bacterial crude extract (zone of inhibition mm) } \\
\hline S. & Samples & \multicolumn{3}{|l|}{ Human pathogenic bacteria } \\
\cline { 2 - 8 } & & $\begin{array}{l}\text { Staphylococc } \\
\text { us aureus }\end{array}$ & $\begin{array}{l}\text { Streptococcul } \\
\text { spyogenes }\end{array}$ & $\begin{array}{l}\text { Bacillus } \\
\text { subtilis }\end{array}$ & $\begin{array}{l}\text { Escherichi } \\
\text { a coli }\end{array}$ & $\begin{array}{l}\text { Klebsiella } \\
\text { pneumoni } \\
\text { a }\end{array}$ & $\begin{array}{l}\text { Pseudomona } \\
\text { s aeruginosa }\end{array}$ \\
\hline 1 & KP1 & 8 & 14 & 12 & 13 & - & 13 \\
\hline 2 & KP 3 & - & 15 & 9 & 15 & - & 11 \\
\hline 3 & KP 6 & 7 & 16 & 14 & 15 & - & 10 \\
\hline 4 & KP 7 & 10 & 9 & 17 & 9 & - & 12 \\
\hline 5 & KP 9 & 12 & 14 & 18 & 13 & 9 & 11 \\
\hline 6 & Standard & 24 & 25 & 27 & 24 & 23 & 24 \\
\hline
\end{tabular}

(-) No activity, standard - Erythromycin

The bacterial crude extract was performed in the antibacterial activity they more inhibition showed by Bacillus subtilisthey followed by Streptococcus pyogenesto the bacteria has the highest zone formed.

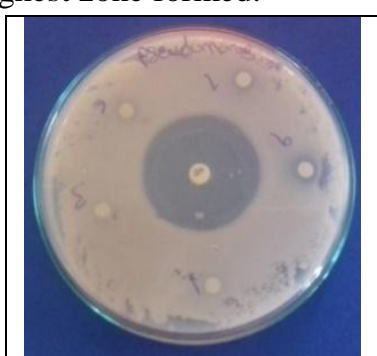

Pseudomonasaeruginosa
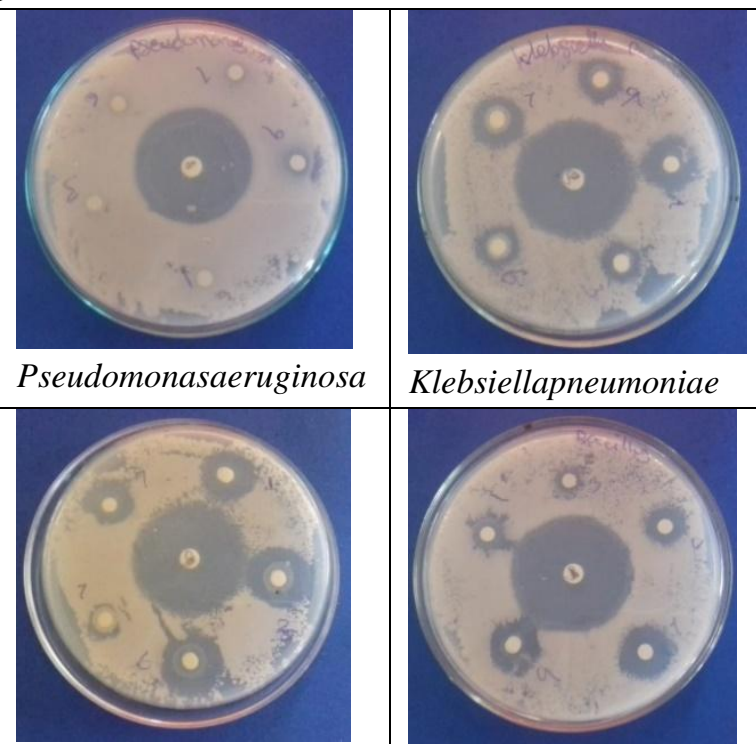

Klebsiellapneumoniae

Streptococcuspyogenes



Bacillus subtilis 


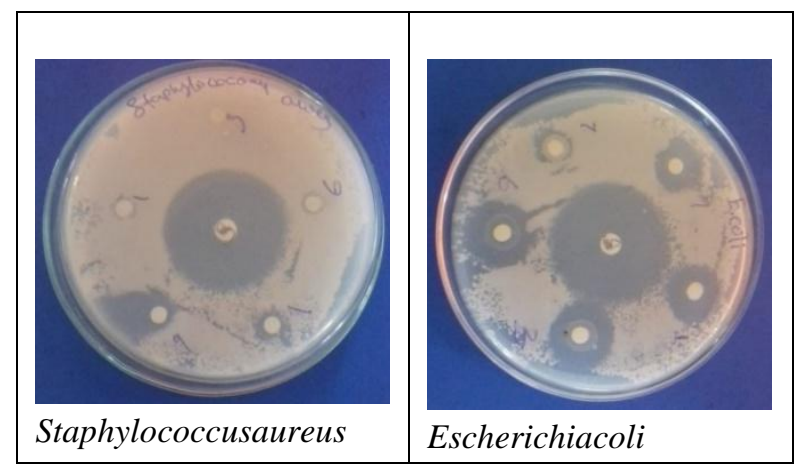

Fig 1: Antibacterial activity of the isolated bacterial crude extract

\section{E. Determination of Minimum Inhibitory Concentration (MIC)}

The Minimum inhibitory concentration (MIC) value of the marine bacterial extracts (KP1, KP3, KP6, KP7 \& KP9) tested against clinical pathogens were ranged between 0.5 $\mu \mathrm{g} / \mathrm{ml}$ to $120 \mu \mathrm{g} / \mathrm{ml}$ and the results were shown in Table -6 . The lowest minimum inhibitory concentration (MIC) (32 $\mu \mathrm{g} / \mathrm{ml})$ was recorded in ethanol crude extract against 6 test human pathogens viz., three Gram-positive bacteria $S$. aureus, B. subtilis, S. pyogenes and three Gram-negative bacteria E. coli, K. pneumoniae, P. aeruginosa.

Tabl-VI: Minimum Inhibition Concentration of isolated bacteria

\begin{tabular}{|l|l|l|l|l|l|l|}
\hline \multirow{2}{*}{$\begin{array}{l}\text { Isolated } \\
\text { bacteria }\end{array}$} & \multicolumn{6}{|l|}{ Human pathogen bacteria (mg/ml) } \\
\cline { 2 - 7 } sample & $\begin{array}{l}\text { S. } \\
\text { aureus }\end{array}$ & B. subtilis & $\begin{array}{l}\text { S. } \\
\text { pyogenes }\end{array}$ & $\begin{array}{l}\text { E. } \\
\text { coli }\end{array}$ & $\begin{array}{l}\text { K. } \\
\text { pneumoniae }\end{array}$ & $\begin{array}{l}\text { P. } \\
\text { aeruginosa }\end{array}$ \\
\hline KP1 & 54 & 67 & 82 & 58 & 104 & 112 \\
\hline KP3 & 58 & 83 & 46 & 63 & 98 & 108 \\
\hline KP6 & 72 & 54 & 76 & 56 & 108 & 95 \\
\hline KP7 & 32 & 28 & 34 & 26 & 34 & 36 \\
\hline KP9 & 34 & 30 & 30 & 28 & 29 & 32 \\
\hline
\end{tabular}

The lowest activity of minimum inhibition concentration was recorded in KP 7 and KP 9 they are the lowest concentration of against human pathogens.

\section{F. Determination of Minimum Bactericidal Concentration (MBC)}

MBC test become another next take a look at that changed into needed to be accomplished as well. MBC take a look at determined the energy of ability solutions as the antibacterial agent. The awareness that used for the MBC test was $3.5 \%$ $\mathrm{v} / \mathrm{v}$ because it confirmed the least B. Subtilis boom within the MIC check. The result proved that the attention of three.Five $\% \mathrm{v} / \mathrm{v}$ bacterial metabolites absolutely killed due to the fact the end result of the streak plate showed no growth of B. Subtilis. Therefore, a solution that carries 3.Five \% v/v of sweet basil leaves crucial oil can be classified as bactericidal awareness. (Table VII).
Table-VII: Minimum Bactericidal Concentration of isolated bacteria

\begin{tabular}{|l|l|l|l|l|l|l|}
\hline \multirow{2}{*}{$\begin{array}{l}\text { Isolated } \\
\text { bacteria }\end{array}$} & \multicolumn{6}{|l|}{ Human pathogen bacteria $(\mathrm{mg} / \mathrm{ml})$} \\
\cline { 2 - 7 } samples & $\begin{array}{l}\text { S. } \\
\text { aurreus }\end{array}$ & $\begin{array}{l}\text { B. } \\
\text { subtilis }\end{array}$ & $\begin{array}{l}\text { S. } \\
\text { plogenes }\end{array}$ & $\begin{array}{l}\text { E. } \\
\text { coli }\end{array}$ & $\begin{array}{l}\text { K. } \\
\text { pneumoniae }\end{array}$ & $\begin{array}{l}\text { P. } \\
\text { aeruginosa }\end{array}$ \\
\hline KP1 & 3.8 & 4.6 & 5.2 & $\mathrm{NE}$ & $\mathrm{NE}$ & 3.8 \\
\hline KP3 & 3.6 & $\mathrm{NE}$ & 4.2 & 6.3 & 6.2 & 4.6 \\
\hline $\mathrm{KP} 6$ & 6.2 & 5.4 & 4.6 & 5.6 & 4.8 & 5.5 \\
\hline $\mathrm{KP} 7$ & 3.2 & 2.6 & 2.4 & 2.6 & 2.4 & 3.4 \\
\hline $\mathrm{KP} 9$ & 2.4 & 3.2 & 2.8 & 2.8 & 3.6 & 3.2 \\
\hline
\end{tabular}

\section{DISCUSSIONS}

Purpose of the examine become to isolate antibiotic-generating microorganisms from the marine soil samples of the Kodiyampalayam coastal place, Tamil Nadu. Marine sediment has been decided on for sampling when you consider that microbial community exceeds in soil than another environment. Soil microorganisms show off high ranges of antibacterial hobby [7]. Many researchers have selected soil to isolate new antibiotics because they are the source of antibiotic-generating micro organism, such as actinomycetes $[14,21,29]$. It has additionally been found out that soil diversity leads to a extensive variety of ecological shops and, therefore, the variety of soil microbes. This result is related to our sampling approach in which the gathered samples are organized from one of a kind locations and special cultivars. Random sampling described by means of [27] is a conventional approach of sample collection; This method turned into supported within the gift have a look at. Morphological characterization became developed the use of the Gram gradation technique, a traditional characterization method followed with the aid of many scientists $[8,14,15]$. Gram deposition shows that each one bacterial isolates are Gram-superb. These consequences have been corroborated with the results of Vadevar and Patil [26], which preferred maximum of the soil isolates.

The isolation of the antibiotic changed into investigated using a number one experiment, observed by a secondary test (order in an office with agar). This is constant with a number of the sooner practices that used the identical techniques to examine isolation. [20,21,25]. Bacterial subculture filtrate was used inside the agar desk diffusion approach for secondary screening. Every desk has loaded within the supernatant of bacterial samples. The samples were loaded by the sterile table in $20 \mu 1$ of every table.

.The antibacterial activity of the isolates KP1, KP3, KP6, KP7 and KP9 was done against the following human pathogens, they are three Gram-positive bacteria S. aureus, B. subtilis, S. pyogenes and three Gram-negative bacteria E. coli, K. pneumoniae, P. aeruginosa. The maximum zone of inhibition was shown by both the isolates KP7 and KP9 against S. aureus. These findings are supported by Saadoun, Kraybay, 2003. Who stated that soil isolates showed the maximum inhibition zone for bacteria. Similarly, [21] 
The isolation showed the maximum inhibition zone of Staphylococcus aureus. But unlike the above results, the maximum inhibition zone was developed at concentrations of $12.5 \mathrm{mg} / \mathrm{ml}$ (minimum inhibition of concentration) $\mathrm{K}$. pneumonia, followed by S. aureus P. aeruginosa and then E. coli.

\section{V.CONCLUSION}

Some of the microbe's metabolites evaluated in nowadays research had potential antibacterial activities against human pathogenic bacteria. The marine bacterial metabolites which can be an alternative to control by developing microbes of pathogens that can be used as a model to the new drugs.

\section{REFERENCES}

1. Alanis, A. J. Resistance to antibiotics: are we in the postantibiotic era? Arch Med Res. 36(6):697-705. (2005).

2. Blunt, J. W., B. R. Copp, M. H. G. Munro, P. T. Northcote, and M. R. Prinsep. Marine natural products. Nat. Prod. Res. 21 (1): 1 - 49 (2004).

3. Cars O, Hogberg LD, Murray M, Nordberg O, Sivaraman S., Lundborg CS, et al., Meeting the challenge of antibiotic resistance. B.M.J. 2008;18:337 a1438.

4. Constancias F, Terrat S, Saby NPA, Horrigue W, Villerd J, Guillemin JP, Biju- Duval L, Nowak V, Dequiedt S, Ranjard L, Prévost-Bouré NC. Mapping and determinism of soil microbial community distribution across an agricultural landscape. Microbiology Open 2015;4:505-17.

5. De Mondena, J.A., S.A.J. Guttierrez, R.A Falchini, J.L. Gallazo, D.E Hughes, J.E. Bailey and J.F. Martin. 1993. Intracellular expression of vitreoscillahaemoglobin improves cephalosporin

6. Dezfully NK, Ramanayaka JG. Isolation, identification and evaluation of antimicrobial activity of Streptomyces flavogriseus, strain ACTK2 from soil sample of Kodagu, Karnataka State (India). Jundishapur J Microbiol 2015;8: e15107.

7. Diddi K, Chaudhry R, Sharma N, Dhawan B. Strategy for identification \& characterization of Bartonellahenselae with conventional \& molecular methods. Indian J Med Res 2013;137:380-7.

8. Faulkner, D.J. Marine natural products. Nat Prod Rep. 19, 1-48 (2002).

9. Feikin DR, Schuchat A, Kolczak M, Barrett NL, Harrison LH, Lefkowitz L, McGeer A, Farley MM, Vugia DJ, Lexau C, Stefonek KR, Patterson JE, Jorgensen JH. Mortality from invasive pneumococcal pneumonia in the era of antibioticresistance, 1995-1997. Am J Public Health 2000;90:223-9.

10. Fenical, W. Chemical studies of marine bacteria: developing a new resource. Chem Rev. 1673-1683. (1993).

11. http://doi.org/10.1136/bmj.a1438.

12. Humphries RM, Linscott AJ. Laboratory diagnosis of bacterial gastroenteritis. Clin Microbiol Rev 2015;28:3-31.

13. Kaur S, Kaur J, Pankaj PP. Isolation and characterization of antibiotic producing microorganisms from soil samples of a certain area of Punjab region of India. Int J Pharm Clin Res 2014;6:312-5.

14. Kumar S, Chaurasia P, Kumar A. Isolation and characterization of microbial strains from textile industry effluents of Bhilwara, India: analysis with bioremediation. J Chem Pharm Res 2016;8:143-50.

15. Luepke KH, Suda KJ, Boucher H, Russo RL, Bonney MW, Hunt TD, Mohr JF. Past, present, and future of antibacterial economics: increasing bacterial resistance, limited antibiotic pipeline, and societal implications. Pharmacotherapy 2017;37:71-84.

16. Maloy Kumar Sahu., K. Sivakumar and Kannan, L. 2007. Marine Realm: A treasure house for bioprospecting. Asian Jr. of Microbiol. Biotech. Env. Sci. 9(1): 191-196.

17. McCarthy, S. A., R.M. Johnson, and D. Kakimoto. Characterization of an antibiotic produced by Alteromonasluteoviolacea Gauthier 1982, 85 isolated from Kinko Bay. Jpn. J. Appl. Bacteriol. 77: 426-432. (1994).

18. Nathan, A., Magarvey., Jessica, M. Keller., Valerie Bernam., Martin Dworkin and Sherman, D.H. 2004. Isolation and characterization of novel marine-derived Actinomycete taxa rich in bioactive metabolites. Appl. Environ. Microbiol. 70(12): 7520- 7529.

19. Nike AR, Hassan SA, AjijolakewuAFBosede. Soil screening for antibiotic - producing microorganisms. Adv Environ Biol 2013;7:7-11

20. Oskay M, Tamer AU, Azeri C. Antibacterial activity of some actinomycetes isolated from farming soil of Turkey. African $\mathrm{J}$ Biotechnol2004;3:441-6.

21. Saadom I, Gharaibeh R. The Streptomyces flora of Badia region of Jordan and its potential as a source of antibiotics active against antibiotic resistant bacteria. J Arid Environ 2003;53:365-71.

22. Sheikh HMA. Antimicrobial activity of certain bacteria and fungi isolated from soil mixed with human saliva against pathogenic microbes causing dermatological diseases. Saudi J Biol Sci 2010;17:331-9.

23. Spellberg B, Guidos R, Gilbert D, Bradley J, Boucher HW, Scheld WM, Bartlett JG, Edwards JJ. Infectious Diseases Society of America. The epidemic of antibiotic-resistant infections: a call to action for the medical community from the infectious diseases society of America. Clin Infect Dis 2008;46:155-64.

24. Thirumalairaj J, Shanmugasundaram T, Sivasankari K, Seenivasan $\mathrm{KN}$, Balagurunathan $\mathrm{R}$. Isolation, screening and characterization of potent marine Streptomyces sp. PM 105 against antibiotic resistant pathogens. Asian J Pharm Clin Res 2015;8:439-43.

25. Wadetwar RN, Patil AT. Isolation and characterization of bioactive actinomycetes from soil in and around Nagpur. Int J Pharm Sci Res 2013;4:1428-33.

26. Williams ST, Vickers JC. The ecology of antibiotic production MicrobEcol1986;12:43-52.

27. Yoshida S, Hiradate S, Tsukamoto T, Hatakeda K, Shirata A Antimicrobial activity of culture filtrate of Bacillus amyloliquefaciens RC-2 isolated from mulberry leaves. Phytopathology 2001;91:181-7.

28. Yunus FN, Khalid ZZ, Rashid F, Ashraf A, Iqbal MN, Hussain F. Isolation and screening of antibiotic producing bacteria from soil in Lahore city. PSM Microbiology 2016;1:1-4.

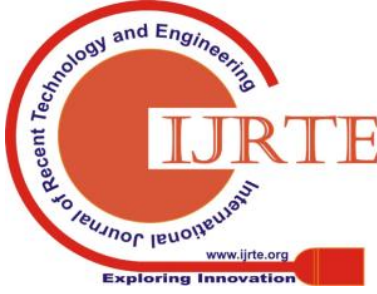

